\title{
Improving English Learning by Gamification with MDA Framework
}

\begin{tabular}{ccc}
\hline \hline Frieska Angelia & Suharjito & Sani Muhamad Isa \\
Computer Science Department & Computer Science Department & Computer Science Department \\
BINUS Graduate Program-Master & BINUS Graduate Program-Master & BINUS Graduate Program-Master of \\
ofComputer Science & ofComputer Science & Computer Science \\
Bina Nusantara University Jakarta, & Bina Nusantara UniversityJakarta, & Bina Nusantara UniversityJakarta, \\
Indonesia 11480 & Indonesia 11480 & Indonesia 11480 \\
frieska.angelia@ymail.com & suharjito@binus.edu & sani.m.isa@binus.ac.id \\
& &
\end{tabular}

Abstract - Information technology is proliferating and drives the learning process toward e-learning. At the moment, people can learn from their gadget through learning sites, applications, or games. However, to improve users' motivation, e-learning must be appealing. Researchers have introduced the concept of gamification to make learning more entertaining. The primary purpose of this research is to understand how the proposed gamification elements using Mechanics, Dynamics, and Aesthetics (MDA) framework improve users' motivation and learning outcomes in English learning. For this research, we use 6-11 framework defining six aspects of emotion and eleven aspects of instinct. We collected users' scores then analyzed them by using a t-test. We also used a questionnaire to access the users' experience. The results suggest that most of the respondents are motivated to learn more deeply. We conclude that the proposed gamification elements improve users' motivation and learning outcomes.

Keywords - Gamification, Game, MDA Framework, 6-11 Framework, Game-based learning, English Language

\section{INTRODUCTION}

Information technology is proliferating and drives the learning process toward e-learning. At the moment, people can learn from their gadget through learning sites, applications, or games. However, based on data collected by Program for International Student Assessment (PISA) in 2015, Indonesia's education quality is ranked 69 th out of 76 countries.

Many factors can affect the quality of education; one of which is interest in learning. Interest is a high tendency and passion or a strong desire for something. The low interest in learning can be seen from the results of a survey conducted by APJII in 2014, where internet used for educational facilities was only $29.3 \%$. To improve users' motivation, e-learning must be appealing. Researches have introduced the idea of gamification to make learning more entertaining.

Gamification is the use of game elements in non-gaming contexts [1]. Gamification has been considered one of the key emergent and widely adopted teaching technologies in education in this decade [2].

Gamification is designed for more enjoyable learning and improves the effectiveness of learning [3]. Gamification encourages users to improve progress through content, motivation, influence behavior, and bring innovation [4]. In addition, it gives user the ability to complete tasks [5]. As shown in Fig. 1 Gamification involves three main areas: technology, games, and learning.

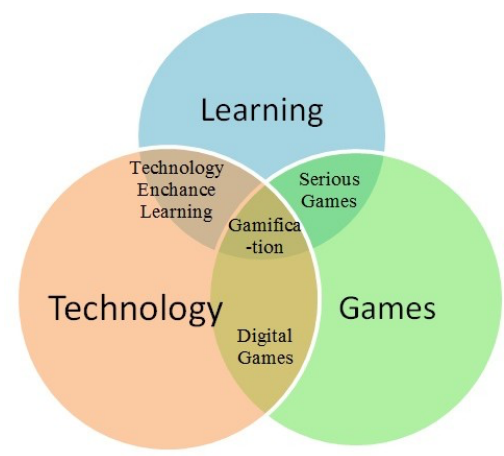

Fig. 1. Three Main Areas of Gamification

According to a survey conducted by Miniwatts Marketing Group on Fig. 2, the most widely used language on the internet as of June 2017 is English. So, it is important to study English.

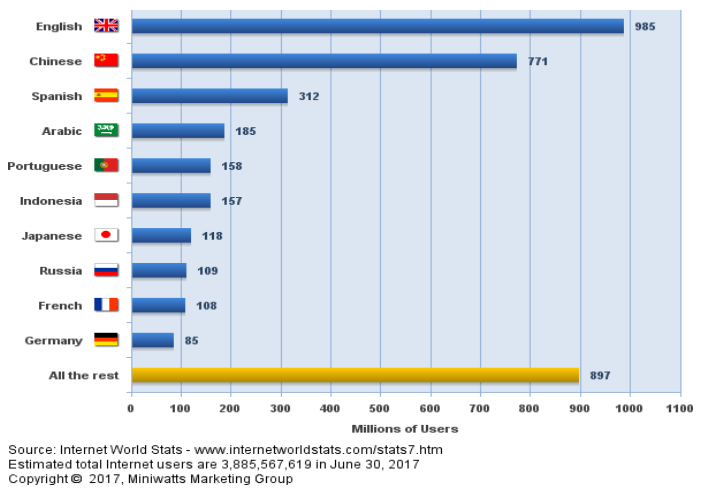

Fig. 2. Top Ten Languages in the Internet

The main purpose of this research is to explore how gamification can increase users' motivation and learning outcome. The study also aims to investigate how the English learning application is made with MDA framework in accordance with English learning materials. 


\section{LITERATURE REVIEW}

\section{A. E-Learning}

E-Learning is an application or game that uses the internet to present learning materials [6]. Some people assume that elearning is limited to web browsers, without the need of software or learning resources. E-learning is the use of information and computer technology to create a learning experiance [7].

E-learning is used to support students in improving their learning. E-learning connect users to the internet, so that they can access the information directly [8].

In "e-learning by design", Horton says that there are seven types of e-learning. The first type of e-learning is Standalone course, a self-taught lesson without interaction with the instructor or classmates. Virtual-classroom course is an online class that is designed like a regular class, either with synchronous online meeting or not. Learning games and simulations are learning with simulation activities that require users to explore. Embedded e-learning is e-learning that exists on other systems, such as software, diagnostic procedures, or online help. Blended e-learning is the forms of e-learning that combines online digital media with traditional classroom methods to achieve a goal. Mobile learning is learning through mobile devices such as PDAs and smartphones. Knowledge management is the use of e-learning, online documents, and conventional media widely to educate the entire population and organization [7].

In the concept of e-learning, Fig. 3 , there is an 8 dimensional e-learning framework created by Badrul Huda Khan. Each dimension has its own focus. This concept is used to develop effective learning [9].

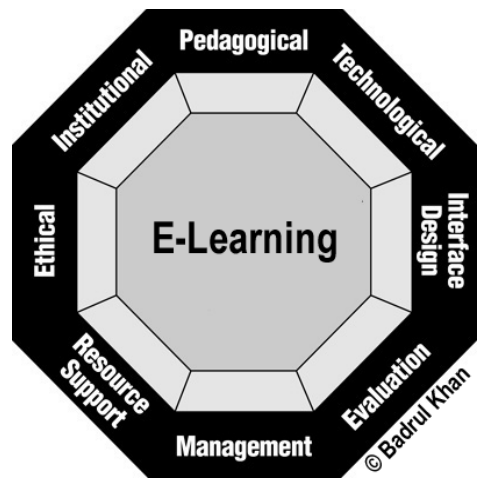

Fig. 3. E-learning Framework [9]

The eight dimensions in the figure above are a selfassessment instrument. Pedagogical dimension is a dimension focuses on teaching and learning, such as content analysis, audience analysis, goal analysis, etc. Technological dimension focuses on technology infrastructure, such as hardware and software. Interface design focuses on the look and experience of using e-learning programs. The evaluation consists of assessment of the learning environment and instruction. Management focuses on maintaining learning environment and information distribution. Resource support is a dimension that checks online support and resources needed in e-learning.
Ethical considerations refer to a dimension that deals with social and political issues, cultural diversity, biases, etc. Institutional is a dimension related to administrative issues [9].

\section{B. Motivation \& Learning Outcome}

Motivation is the impulse to realize deeds in the form of activity to achieve a particular need or purpose [10]. Learning outcome is a statement of the main points expected to be achieved by the learners at the end of the lesson. Learning outcomes clarify the purpose of the learning [11].

Learning Outcome can be measured based on three aspects: knowledge, skills, and attitudes. Here are the characteristics of learning outcome: reflecting broad and specific conceptual knowledge; reflecting important knowledge, skills or attitudes; and focusing on learning outcomes and expected outcomes

With this learning outcome, it is expected that there will be Consistent improvement with the learning outcomes offered, accountability that mean expectations for learning outcomes are clearly defined and assessment processes are expected to assist in the identification of progress outcomes, and accessibility (clear results enable learners to demonstrate achievement of results).

\section{Game}

Game is a play activity conducted in the context of pseudo reality, where participants try to achieve at least one nontrivial goal by acting according to the rules. A game includes rules and goals. The essential elements of the game are play, pretending, goals, and rules. Play is a participative form of entertainment, while books, movies, and theaters are a form of presentation. Pretending is creating an abstract reality in mind, which is one element of the game. A game must have at least one goal. The purpose of the game is limited by rules and limits. Rules are definitions and instructions approved by players during the game. Every game has rules, even if the rules are not written [12].

According to Adams [12], the game is called balance if not too easy or too difficult and player ability becomes an important factor in determining its success. A well-balanced game has the following characteristics. First, the game provides meaningful choices. Game lets players to choose strategies in approaching the challenge of the game. There is no definite strategy. Every strategy has a chance to win. Second, the role of chance is not so great that player skills become irrelevant. Players may have bad luck, but better players should be more successful than players who do not. Third, the player perceives the game to be fair. The player's perception of fairness involves a number of factors and becomes complicated in the absence of an opponent. Fourth, the game's level of difficulty must be consistent. The difficulty level of the game is still within reasonable limits so as not to surprise the player with a sudden jump or fall. The difficulty level does not change unexpectedly, especially on single level games.

\section{Gamification}

Gamification is the use of game design elements in nongaming contexts to engage people, motivate actions, improve learning and solve problems. Gamification is usually implemented in the forms of scoring elements, such as points, levels and achievements [1]. Gamification involves three main areas: technology, games and learning. 
As one method of learning, gamification has several advantages. The learning process becomes more fun, encouraging users to complete their learning activities, helps users focus more and understand the material being studied and provide an opportunity for users to explore [13].

According to Gilbert [14], gamification system has several main characteristics such non-game goals, game concepts and components, the role of data, emergent opportunities, and pervasiveness. There are 7 main game elements applied in gamification, as follows [15].

The points system is one of the game elements given to the player after completing a particular mission. Through this system, game designers can assess how players interact with their systems, design outcomes, and make the right adjustments.

In most games, the level becomes a progress indicator. In the application of game design, level is not always linear. It does not mean that level is made based on multiples, for example level 1100 EXP, level 2200 EXP, and so on. For some games, the level can be a determinant of the difficulty of the game and therefore requires level balancing. Progress can also be displayed by a progress bar.

Leaderboards are used to make comparisons simple and easy to understand by players. Leaderboard is displayed in order from the highest to the lowest. For example, here is the leaderboard of Dokapon Kingdom game in Fig. 4.

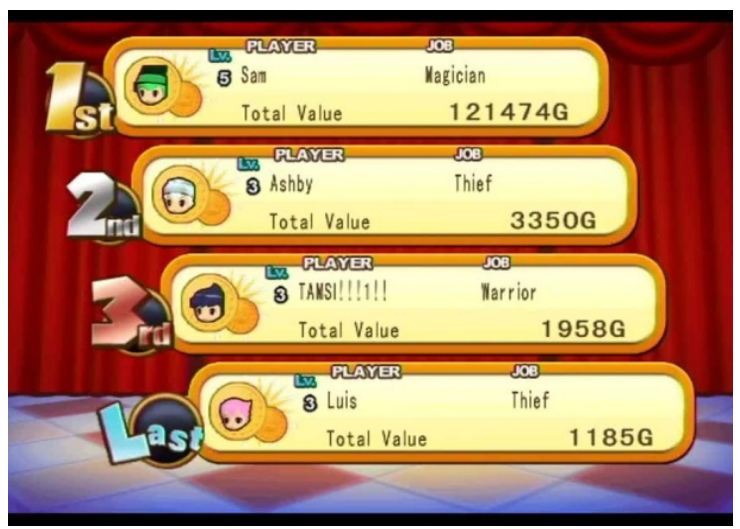

Fig. 4. Example of Leaderboard

For game designers, badges can be used to promote their products and services. Badges are also markers that a goal has been completed or progress game to date. Fig. 5 indicates some badges in the Farmville game, for example, "High Roller" if the player has collected enough money and scoredall ribbons.

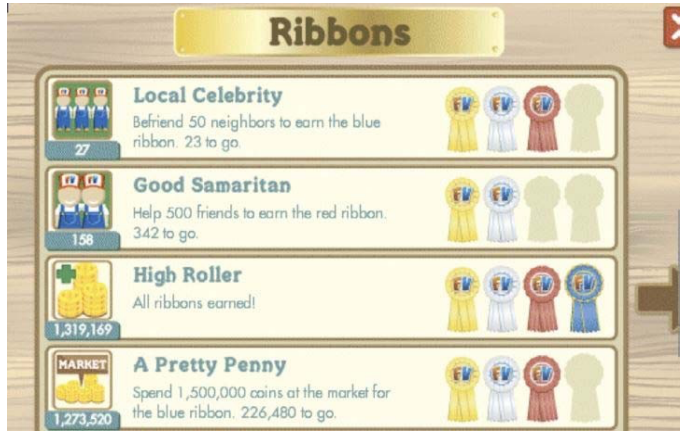

Fig. 5. Example of Badges [15]

Challenges and quests give players directions on what they should do. This will give players experience and challenges to explore the game further.

Onboarding is the act of bringing a beginner into the system, which in the first minute will determine the impression of the system. This onboarding can also be done by providing tutorials for beginners. However, it is expected that the onboarding is not too long because it can make players bored before trying the game. Fig. 6 shows an exampleof Cut The Rope Onboarding.

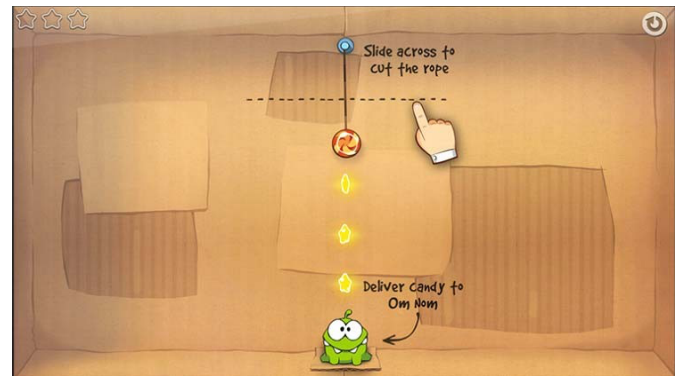

Fig. 6. Example of Onboarding

Engagement Loops is a left impression that keeps players coming back to play the game. As Fig. 7 indicates, it is divided into four engagements.

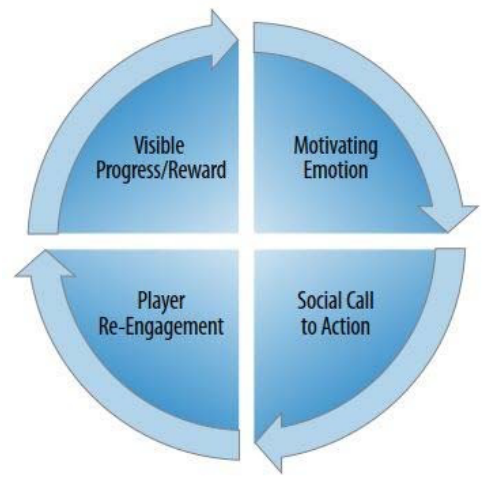

Fig. 7. Social Engagement Loop [15]

Here is an example of engagement loops on Twitter: Emotional motivation (for example: collect and ranking), Player re-engagement (for example: tweets and retweets), Social call to action (for example: follows retweets), and Visible progress / reward (for example: list followers) 


\section{E. Gamification User Characteristic}

According to Richard Bartle, there are 4 characteristics of user gamification [14]. Fig. 8 shows that user gamification is divided into 4 quadran.

Killers is a user's characteristic is usually a new user and works based on parameters on the system. This user characteristic is also known as griefers and is the smallest population of all user characteristics.

The Achievers already understand the system and want to improve its status by passing high-level challenges. These users are happy with competitive games, but defeat can make him lose interest [15].

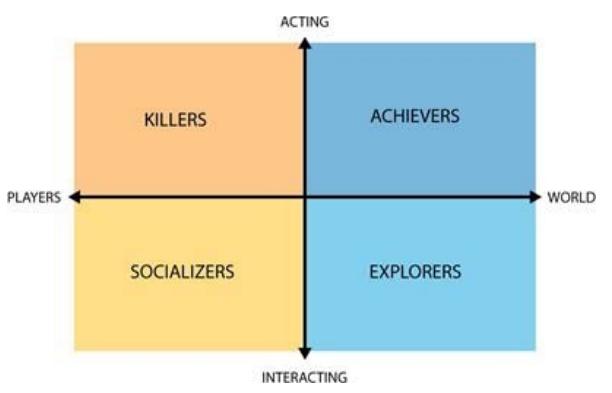

Fig. 8 Gamification User Characteristic [15]

Socializers are at the core of the success of MMORPG and understand all the components of the system with social interaction. This social interaction usually makes the game last longer.

Explorers are familiar with the system and do not focus on winning, but exploration. The purpose of these users is experience.

\section{F. MDA Framework}

Mechanics, Dynamics, and Aesthetics (MDA) Framework is a formal structure used to analyze and understand gaming elements. Fig. 9 shows that in the MDA Framework, the user takes a "bottom-up" approach, while the software architecture takes a "top-down" approach [16].

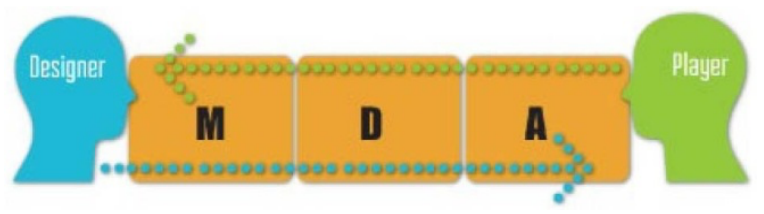

Fig. 9. MDA Framework [14]

Mechanics is a function that allows users to take actions. Mechanics is a guide for players in accordance with established rules. In games, dynamics is the relationship or interaction between the user and the game system, discussing how the user responds to the existing mechanics on the system. Aesthetics deals with emotional responses in games that affect users. This emotion comes from the dynamics of a game system.

\section{G. The 6-11 Framework}

"The 6-11 Framework" is a new game analysis and design methodology defined to help game designers. This framework is contextualized in MDA and explained through relevant examples. The "6-11 Framework" addresses a new taxonomy for game aesthetics related to actual game dynamics. "The 6-11 Framework" proposes that games can be so engaging at a subconscious level because they successfully rely on a subset of basic emotions and instincts [17].

This framework focuses on six emotions and eleven instincts that are recurrent in psychology and widely analyzed in a number of well known treatises [17].

The six emotions are as follows. Fear is one of the most common emotions in game that can be triggered by survival horor games or dungeon explorations in RPG games. Anger, a powerful emotion used as a motivational factor to play again. Joy/Happiness is one of the most relevan emotions for having fun while playing games, for example reward after completing mission. Pride can be represented by reward players and make them proud of their achievements. To represent sadness, game designers reach new artistic heights and create more complex and mature themes. Excitement is the consequence of successfully triggering other emotions and/or instincts.

The eleven core instincts are Survival (Fight or Flight), the most fundamental and primordial of all instincts, triggered when faced a life threat; Self Identification, people control a fictional character and imagine of being like their character; Collecting is the instinct can link to a variety of different emotions; Greed is the instinct to collect valuable items, goods or resources just for himself/herself; Protection/Care/Nurture push people to care and help those in need; Aggressiveness usually lead to violence when coupled with greed or anger; Revenge is a motivational force used in game to advance storyline or give a reason why we need to annihilate the bad guy; Competition is the instinct that exploits human desire to be superior to others, e.g leaderboards; Communication is the social need to express ideas or just chat, e.g talk with NPC to get information or sharing experiences with other players; Exploration / Curiosity pushes people towards the unknown; and Color Appreciation is the use of colors, e.g scene and environtments, that attract people.

\section{RELATED WORK}

Besides the study of gamification elements and its framework, we also reviewed related works conducted by other researchers. The studies focused on gamification rather than onfull games.

$\mathrm{Su}$ and Cheng [18] analyzed how a gamified learning approach influences science learning. The participants of this study consisted of 3 Taiwaneses of four grade classes with 102 students. The participants of the experimental group used a MGLS application, incorporating a game-informed learning approach in an outdoor educational environment. Data were analyzed with ARCS questionnaire and post-test result. The participants who used an MGLS application had a better learning achievement.

Sari, Utami and Fatta [19] conducted research which focused on tenses learning with gamification elements (points, badges, and trophies) in a web form. The gamified system was made with 2 elements of Marczewski's Gamification Framework. Test case was conducted with Black Box Testing. 
Sze Lui LAM [20] is a senior instructor in the English Language Center at the University of Macau. Her research interests include motivation, learning styles and strategies, and elearning. She made a case study which focused on 2 online flash games for vocabulary learning and was conducted on 5 groups of students between 18-20 years. The research data were obtained through survey and analyzed using t-test. Based on her case study, she concluded that gamification makes education more interesting and engaging.

Garland [21] conducted a study which involved 2,838 people. The research method comprised literature study, coding and rationale moderator. The analysis was done using Meta analysis and random effects model analysis. The conclusion of this thesis is that gamification could have beneficial effects in language classroom.

V. Nedeva and Em. Dimova [22] discussed the advantages of e-learning in English language training. The researchers used technology to support learning through LMS with 6 kinds of programs. Based on the research results, $95 \%$ quality of education can be reached by using information technologies.

Fatima Faya Cerqueiro and Milagros Chao Castro [23] examined the use of 3 different board games. The study was conducted with small groups given a test during the process. It was found that the games can increase interest and participation in the class.

Andras Ketyi [24] conducted research to identify the effectiveness of Lifeline application in Language learning for 2 weeks. The data of the research were obtained using a questionnaire. The application is compared with previous app research. The time spent with the application increased intensively along with the average study frequency.

Strmečki, Bernik and Radošević [25] conducted research as part of a short-term research project supported by the University of Zagreb. The study was conducted with 2 platforms (1 with gamification and 1 without gamification) using Moodle (moodle.org). Moodle is an open source application for designing online learning. The respondents of this study were 55 people divided into 4 groups. Data were collected through questionnaires, pre-test and post-test. Data analysis was done using t-test.

Morten Grina Myhre [26] analyzed gamification mechanics in mobile language learning. The respondents of this study were Norwegian immigrants studying Norwegian Language. The research was initially conducted by conducting interviews (descriptive and relational research methods). Measurement of satisfaction was done by SUS (System Usability Scale). Data were collected using questionnaires and analyzed using statistical calculations of SPSS (Statistical Package for the Social Sciences), paired-samples t-test), and Wilcoxon signed ranks test.

Gafni, Achituv, and Rachmani [27] conducted a study which determined the impact of Mobile Assisted Language Learning on learning process using Dualingo application. Data were obtained through questionnaires before and after using the application. The data were measured using Cronbach's Alpha. Beliefs, intentions and feelings were measured using SmartPLS and t-test. It was found that gamification of m-learning applications can promote and en-courage the use of these applications.

Christopher Cheong, France Cheong, and Justin Filippou [28] from RMIT University conducted using a mobile quizbased web application on 3 subjects related to IT. Data were collected for 4 weeks through a 5-point Likert scale questionnaire. The effect of the gamified learning activity was evaluated in terms of three dimensions: engagement, enjoyment, and learning.

Osipov, Volinsky, Nikulchev, and Prasikova [29] discussed the application of new learning "i2istudy" as a medium of learning live interaction. The research was measured by the number of application users, number of teachers and time spent in the application as a teacher and as a student. Based on the conducted experiments, users not only spent more time in the system, they also invited their friends to join them.

From 12 papers that we examined, we made a report about its MDA Framework. We used 6-11 Frameworks to analyze it. Table I shows the gamification elements included in the study.

TABLE I. GAMIFICATION ELEMENT

\begin{tabular}{|l|l|}
\hline \multicolumn{1}{|c|}{ Gamification Element } & \multicolumn{1}{c|}{ Included in the study } \\
\hline Points & {$[19][20][26][28][29]$} \\
\hline Level & {$[18][19][24][27]$} \\
\hline Leaderboard & {$[24][25][27][28]$} \\
\hline Badges & {$[19][24][25][27]$} \\
\hline Challenges \& Quests & \\
\hline Onboarding & {$[23][26]$} \\
\hline Engagement Loops & {$[19][25][27][29]$} \\
\hline
\end{tabular}

From Table I, we can see that points is the most widely used element. After that, level, leaderboard, badges and engagement loops are the second most widely used element.

Table II represent 6-11 Framework that included in the study. Most of them use "color appreciation", "competition" and "pride".

TABLE II. 6-11 FRAMEWORK

\begin{tabular}{|l|l|}
\hline \multicolumn{1}{|c|}{ Emotions } & \multicolumn{1}{c|}{ Included in the study } \\
\hline Fear & - \\
\hline Anger & - \\
\hline Joy/Happiness & {$[18][22][24][26][27]$} \\
\hline Pride & {$[19][23][25][26][27][28][29]$} \\
\hline Sadness & - \\
\hline Excitement Instinct & {$[20][23]$} \\
\hline \multicolumn{1}{|c|}{ Included in the study } \\
\hline Survival (Fight or Flight) & {$[24][27]$} \\
\hline Self-Identification & {$[24]$} \\
\hline Collecting & {$[19][20][29]$} \\
\hline Greed & - \\
\hline Protection/Care/Nurture & - \\
\hline Aggressiveness & - \\
\hline Revenge & - \\
\hline Competition & {$[19][23][25][26][27][28]$} \\
\hline Communication & {$[18][24][28][29]$} \\
\hline Exploration/Curiosity & {$[18][24]$} \\
\hline Color Appreciation & {$[18][20][22][23][25][26][27]$} \\
\hline
\end{tabular}


Table III shows the type of studies based on the method used in the study. Table III show that the studies used quantitative method. This research uses survey or questionnaires to obtain data. Data were analyzed using certain methods, such t-test, meta analysis, etc.

TABLE III. TYPES OF STUDIES

\begin{tabular}{|l|l|}
\hline \multicolumn{1}{|c|}{ Method } & \multicolumn{1}{c|}{ Paper } \\
\hline $\begin{array}{l}\text { Qualitative } \\
\text { (include interviews and other qualitative } \\
\text { observations) }\end{array}$ & - \\
\hline $\begin{array}{l}\text { Quantitative } \\
\text { (include experiments, log data analysis and } \\
\text { quantitative questionnaires) }\end{array}$ & {$[18][21][22][23][25]$} \\
\hline $\begin{array}{l}\text { Mixed methods } \\
\text { (include both qualitative and quantitative } \\
\text { method) }\end{array}$ & {$[19][20][24][26][28]$} \\
\hline
\end{tabular}

\section{METHODS}

We used literature review to obtain more knowledge which is related to this research. The literature review uses books, paper, articles, and journals as references. We searched, selected, analyzed, and reported the literature review. Based on the result, we made our gamification model for English learning application system.

We implemented our gamification elements into an English learning application. The learning application contains 100 questions that will appear randomly. Users must answer the questions as much as they can before the time runs out $(90$ seconds). Users get 10 points if they answer the question correctly and -3 points if their answers are wrong. Every time the users give a wrong answer, the system will show the correct one. Users can download it on Google Play Store (https://play.google.com/store/apps/details?id=com.RenhaSky.E nglishQuizGame). Fig. 10 shows the startscreen of "Do You Speak English" learning application and Fig. 11 shows the gameplay of the learning application

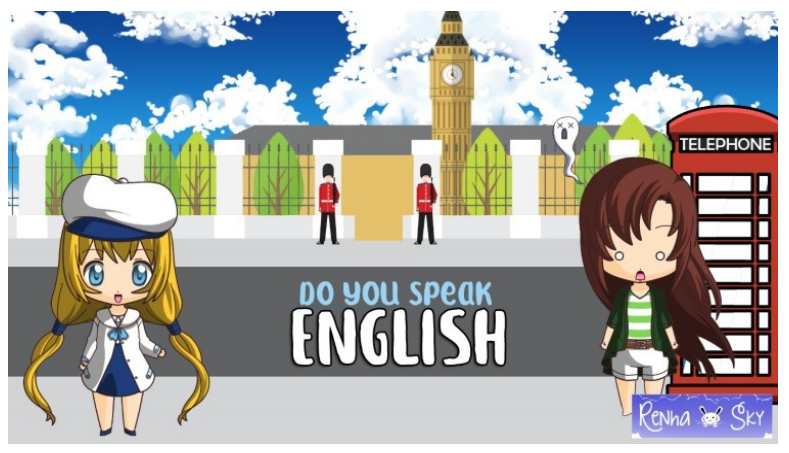

Fig. 10. "Do You Speak English” StartScreen

There are features of learning materials and shop. This learning application also comes with google leaderboard and achievements, so that users can collect badges when they finish the mission and compete for higher score with other users. We collected the data of users' scores and compare them to know the progress of English learning. We also used questionnaire to know the users' experience.

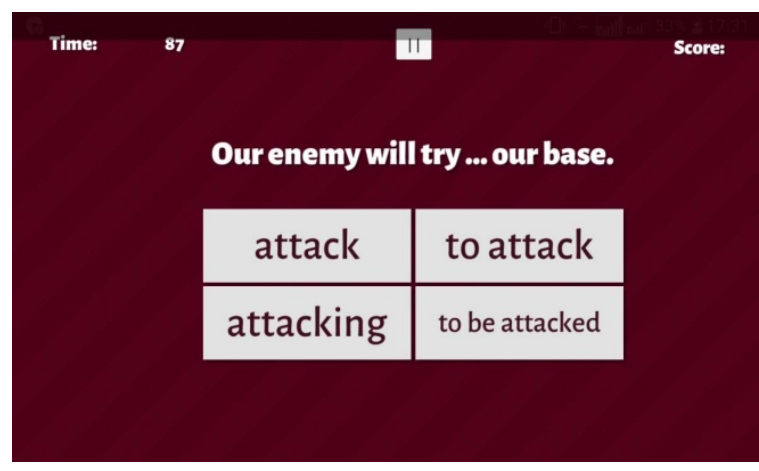

Fig. 11. "Do You Speak English" GamePlay

Based on similar previous studies, the researchers made gamification using 3 emotions and 3 instincts shown on Fig. 12. The implementation is explained in Table IV.

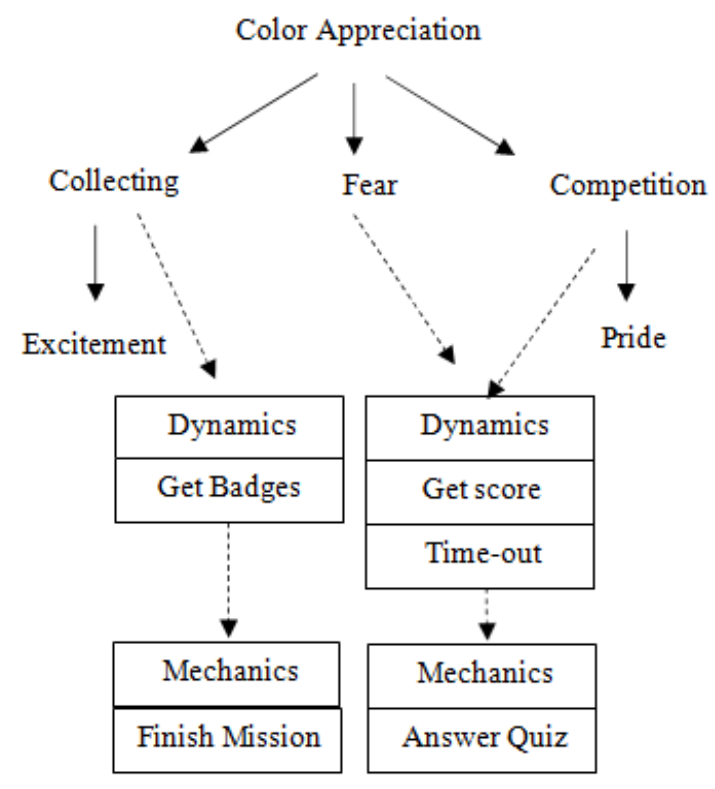

Fig. 12. Proposed Gamification with 6-11 Framework

TABLE IV. PROPOSED GAMIFICATION

\begin{tabular}{|l|l|}
\hline \multicolumn{1}{|c|}{ Emotion } & \multicolumn{1}{c|}{ Description } \\
\hline Excitement & $\begin{array}{l}\text { Users feel interested with learning application because } \\
\text { they want to get a high score and learn the material }\end{array}$ \\
\hline Fear & Time is limited to 90 seconds \\
\hline Pride & Proud of having a high rank \\
\hline \multicolumn{1}{|c|}{ Instinct } & \\
\hline Collecting & Collect badges \\
\hline Competition & Compete with others to get the highest score \\
\hline Color Appreciation & Color diversity used in application \\
\hline
\end{tabular}

\section{RESULT \& DISCUSSION}

The authors collected data of users' scores and took 15 respondents as samples. The scores were divided into 2 groups. X1 is the average score for the first trial when users immediately answered the question without looking at other features. X2 is the average score for the second to fifth trial where users have seen the features available in " Do You Speak English ". The 
scores are then used to find the values of Q1, Q2 (Median), and Q3. Table V shows the calculation results.

TABLE V. USERS' SCORES OF Q1, Q2 AND Q3

\begin{tabular}{|l|c|l|l|l|l|l|}
\hline & $\begin{array}{c}\text { Average } \\
\text { Score }\end{array}$ & $\begin{array}{c}\text { Min } \\
\text { Value }\end{array}$ & \multicolumn{1}{|c|}{ Q1 } & \multicolumn{1}{|c|}{ Q2 } & \multicolumn{1}{|c|}{ Q3 } & $\begin{array}{c}\text { Max } \\
\text { Value }\end{array}$ \\
\hline $\mathrm{X} 1$ & 109.53333 & 12 & 84 & 97 & 124.5 & 238 \\
\hline $\mathrm{X} 2$ & 186.36666 & 57.25 & 127.375 & 155 & 230.125 & 378.5 \\
\hline
\end{tabular}

The authors made a box plot diagram based on the value of Q1, Q2 and Q3. Fig. 13 show the box plot diagram.

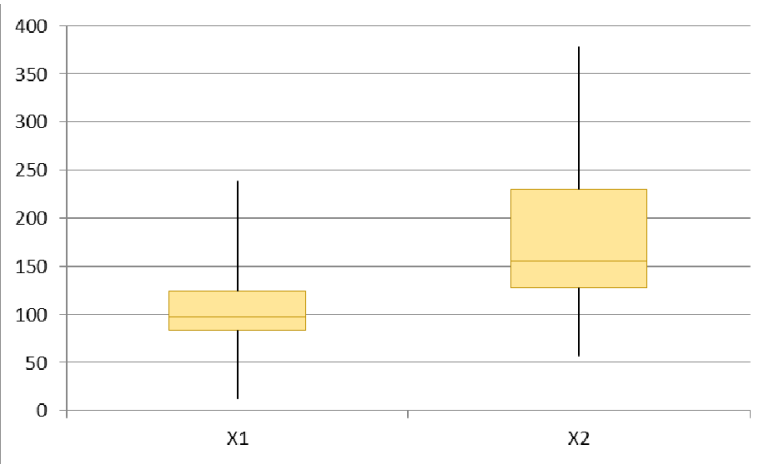

Fig. 13. Box Plot Diagram

In this study, the authors use T-test to prove the hypothesis.

The data retrieved are X1 and X2 from Table V.

HO : The use of gamification in learning English does not improve learning outcome

H1 : The use of gamification in learning Englishimproves learning outcome

Table VI shows calculation results of variance and pearson correlation. Observations refer to the number of respondents.

TABLE VI. PAIRED SAMPLES T-TEST

\begin{tabular}{|c|c|c|}
\hline & $\mathrm{X} 1$ & $\mathrm{X} 2$ \\
\hline Variance & 2934.409524 & 7467.516667 \\
\hline Observations & 15 & 15 \\
\hline $\begin{array}{c}\text { Pearson } \\
\text { Correlation }\end{array}$ & 0.618932912 & \\
\hline
\end{tabular}

Based on the comparison of $t$ stat and $t$ table in Table VII, it can be seen that the value of $t$ stat (4.383993752) is greater than $\mathrm{t}$ table (2.144786688). Based on the probability value and alpha value, the probability value Sig. 2 tail $=0.000623744$ is smaller than 0.05 . Therefore, the null hypothesis (H0) is rejected.

TABLE VII. PAIRED SAMPLES T-TEST $(\mathrm{A}=0,05)$

\begin{tabular}{|c|c|c|}
\hline & & Description \\
\hline $\mathrm{df}$ & 14 & \\
\hline $\mathrm{t}$ Stat & 4.383993752 & \\
\hline $\mathrm{P}(\mathrm{T}<=\mathrm{t})$ one-tail & 0.000311872 & $\mathrm{P}$ value on SPSS \\
\hline $\mathrm{t}$ Critical one-tail & 1.761310136 & $\mathrm{t}$ table \\
\hline $\mathrm{P}(\mathrm{T}<=\mathrm{t})$ two-tail & 0.000623744 & $\mathrm{P}$ value on SPSS \\
\hline $\mathrm{t}$ Critical two-tail & 2.144786688 & $\mathrm{t}$ table \\
\hline
\end{tabular}

The authors also collected data using questionnaires. Here is the result from our questionnaires with responses from 32 respondents. The majority of the respondents aged 17-25 years old and $\geq 25$ years old. Most respondents use gadget with android platform.

The user interface of "Do You Speak English" has fulfilled

8 golden rules and 5 human factors central to community evaluation. Respondents feel interested with "Do You Speak English". The respondents know about gamification and its elements. On our learning application, we already used all gamification elements. Fig. 14 shows the opinion of the respondents about gamification elements. The most used elements based on the respondents' responses are points and badges.

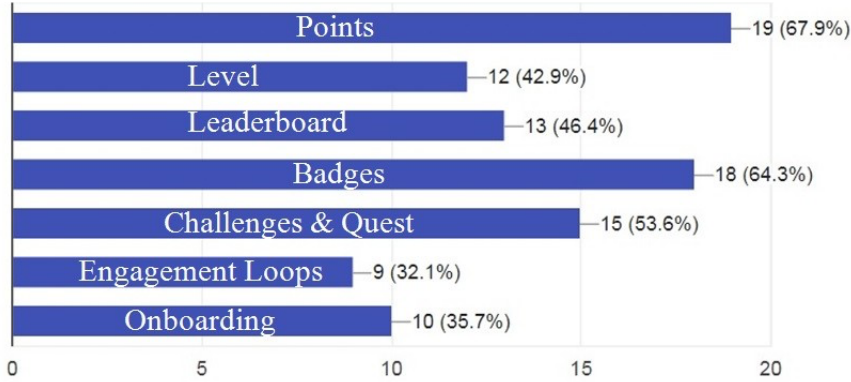

Fig. 14. Gamification Element Chart

Most of the respondents did not know about MDA Framework before. We tried to give the definition and explanation about MDA Framework. The following is the response from 32 respondents. 25 respondents felt excited when using "Do You Speak English". 15 respondents thought that this game used emotion element such as pride and happiness.
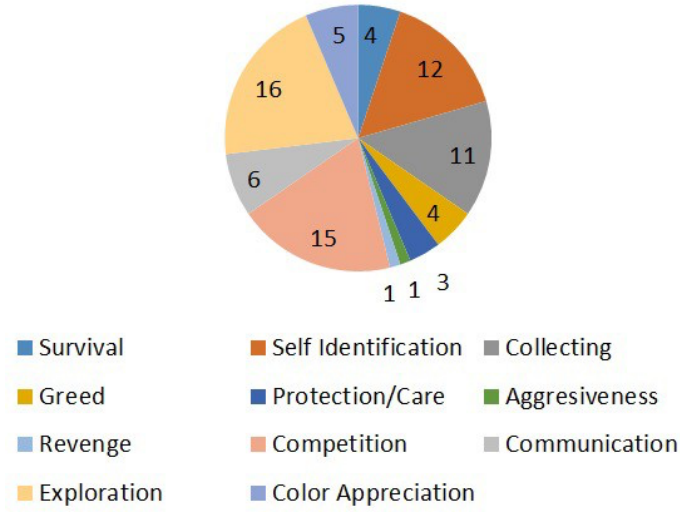

Fig. 15. Instinct Element Chart

As Fig. 15 indicates, most of the respondents thought that the instinct elements used in "Do You Speak English" are exploration (16 people), competition (15 people), self identification (12 people) and collecting (11 people).

There are some differences between our proposed gamification on Fig. 12 with the respondents' responses. We propose 3 emotions and 3 instincts, which are color appreciation, collecting, fear, competition, excitement and pride. Table VIII 
shows the differences between our proposed gamification and respondents' responses.

TABLE VIII. PROPOSED GAMIFICATION VS RESPONDENTS RESPONSE

\begin{tabular}{|l|c|c|}
\hline \multicolumn{1}{|c|}{ Emotion } & $\begin{array}{c}\text { Proposed } \\
\text { Gamification }\end{array}$ & $\begin{array}{r}\text { Respondents } \\
\text { Response }\end{array}$ \\
\hline Excitement & $\mathrm{X}$ & $\mathrm{X}$ \\
\hline Fear & $\mathrm{X}$ & $\mathrm{X}$ \\
\hline Pride & $\mathrm{X}$ & $\begin{array}{c}\text { Respondents } \\
\text { Response }\end{array}$ \\
\hline Happiness & $\begin{array}{c}\text { Proposed } \\
\text { Gamification }\end{array}$ & $\mathrm{x}$ \\
\hline \multicolumn{1}{|c|}{ Instinct } & $\mathrm{x}$ & $\mathrm{x}$ \\
\hline Collecting & $\mathrm{x}$ & $\mathrm{x}$ \\
\hline Competition & $\mathrm{x}$ & \\
\hline Color Appreciation & & \\
\hline Exploration & & \\
\hline Self Identification & & \\
\hline
\end{tabular}

\section{CONCLUSION}

Based on evaluation, the proposed gamification has motivated respondents to learn more deeply, use all elements of gamification shown on Fig. 14, and prove that English learning with gamification can increase learning outcome based on our paired t-test result on Table VII.

\section{REFERENCES}

[1] S. Deterding, D. Dixon, R. Khaled and L. E. Nacke, "Gamification Toward A Definition," in Proceedings of the 2011 annual conference on Human factors in computing system, 2011.

[2] Johnson, L., Adams Becker, S., Estrada, V., Freeman, A., NMC Horizon Report:2014 Higher Education Edition. Texas : The New Media Consortium, 2014.

[3] S. Kim, K. Song, B. Lockee and J. Burton, Gamification in Learning and Education: Enjoy Learning Like Gaming, Switzerland: Springer, 2017.

[4] K. M. Kapp, The Gamification of Learning and Instruction Fieldbook: Ideas into Practice, San Francisco: John Wiley \& Sons, 2013.

[5] T. Pickard, "5 Statistics That Prove Gamification is The Future of The Workplace," (2017). [Online]. Available: https://www.business.com/artic

les/5-statistics-that-prove-gamification-is-the-future-of-the-workplace/.

[6] L. D. Prasojo dan R., Teknologi Informasi Pendidikan, Yogyakarta: Gava Media, 2011.

[7] W. Horton, e-Learning by Design, United State: John Wiley \& Sons, 2011.

[8] M. Urh, G. Vukovic, E. Jereb and R. Pintar, "The model for introduction of gamification into e-learning in higher," in 7th World Conference on Educational Sciences, Greece, 2015.
[9] S. L. Danver, The SAGE Encyclopedia of Online Education, United State: SAGE Publications, 2016.

[10] H. Surya, Menjadi Manusia Pembelajaran, Jakarta: Elex Media Komputindo, 2009.

[11] S. Lesch dan G. B. College, "Learning Achieved by The End of A Course or Program," (2012). [Online]. Available: http://liad.gbrownc.on.ca/programs/InsAdult/currlo.htm.

[12] E. Adams, Fundamentals of Game Design (2nd ed.), California: Pearson Education, Inc., 2010.

[13] H. Jusuf, "Penggunaan Gamifikasi dalam Proses Pembelajaran," Jurnal TICOM, vol. 5, pp. 1-6, 2016.

[14] S. Gilbert, Designing Gamified Systems, Oxon: Focal Press, 2016.

[15] G. Zichermann dan C. Cunningham, Gamification by Design, Sebastopol: O'Reilly, 2011.

[16] R. Hunicke, M. LeBlanc dan R. Zubek, "MDA: A Formal Approach to Game Design and Game Research,” 2004.

[17] R. Dillon, "The 6-11 Framework: A new methodology for game analysis and design," Proceedings Game-On Asia Conference, pp. 2529, 2011.

[18] C.-H. Su dan C.-H. Cheng, "A mobile gamification learning system for improving the learning motivation and achievements," Journal of Computer Assisted Learning, pp. 268-286, 2015.

[19] B. W. Sari, E. Utami and H. A. Fatta, "Penerapan Konsep Gamification pada Pembelajaran Tenses Bahasa Inggris Berbasis Web," Jurnal Ilmiah SISFOTENIKA, vol. 5, pp. 155-166, 2015.

[20] LAM Sze Lui, Use of Gamification in Vocabulary Learning: A Case Study in Macau, 2014

[21] Christopher M. Garland, Gamification and Implications for Second Language Education: A Meta Analysis, 2015.

[22] V. Nedeva \& Em. Dimova, Some Advantages of e-Learning in English Language Training, 2010.

[23] Fatima Faya Cerqueiro \& Milagros Chao Castro, Board-games as review lessons in English language teaching: useful resources for any level, 2015.

[24] Andras Ketyi, From Mobile Language Learning to Gamification : an Overlook of Research Results with Business Management Students over a Five-Year Period, 2016.

[25] Daniel Strmečki, Andrija Bernik and Danijel Radošević, Gamification in E-Learning : Introducing Gamified Design Elements into E-Learning Systems, 2016

[26] Morten Grina Myhre, Gamification in Mobile Language Learning : Improving User Satisfaction for Norwegian Immigrants, 2015.

[27] Ruti Gafni, Dafni Biran Achituv, \& Gila Joyce Rachmani , Learning Foreign Languages Using Mobile Applications, 2017.

[28] Christopher Cheong, France Cheong, \& Justin Filippou, Quick Quiz : A Gamified Approach for Enchancing Learning, 2013.

[29] Ilya V. Osipov, Alex A. Volinsky, Evgeny Nikulchev, \& Anna Y. Prasikova, Study of Gamification Effectiveness in Online e-Learning Systems, 2015 